\title{
Penerapan Paten Sejak UU Paten No. 6 Tahun 1989 hingga UU Paten No. 13 Tahun 1997: Pengalaman Indonesia Selama Ini
}

\author{
Insan Budi Maulana
}

\begin{abstract}
Abstrak
Since the enactment of Patent Law 1989 No. 6 until March 1998, there had been 21.761 patent applications received by the Indonesian Patent Office, and only $3 \%$ of which had been domestic applications. These had not been significant if compared to some other countries like Japan which has its patent applications as many as 300.000 animally. Does it indicate the law capability of Indonesian people to conduct patentable inventions and innovations? Does it only mean the law consciousness of Indonesian inventors to have their technological inventions patented? Does it merely imply the economic factors?
\end{abstract}

\section{Pendahuluan}

Sesungguhnya Indonesia telah menerapkan UU Paten sejak masa penjajahan Belanda, yaitu melalui reglement Industriele Eigendom 1912 yang mengesahkan pelaksanaan paten, merek dan desain dengan me-. ngacu pada peraturan-peraturan yang serupa yang terjadi di Belanda. Ketentuan tersebut seakan "tidak diberlakukan lagi" sejak ditetapkan "Pengumuman Menteri Kehakiman" tanggal 12Agustus 1953 Nr. J.S.5/4114.BN.195369, ' walaupun Pasal II Aturan Peralihan UUD 1945. menyatakan bahwa segala badan Negara dan peraturan yang masih ada langsung berlaku selama belum diadakan yang baru menurut Undang-Undang Dasar ini. Dengan adanya pengumuman tersebut Indonesia hanya menerima permohonan permintaan paten namun proses permintaan paten itu

'Dalam pengumuman Menteri Kehakiman tidak disebutkan kapan UU Paten akan diberlakukan, dan bagaimana akibat pendaftaran permintaan paten yang diterima sementara itu. 
akan dilakukan setelah diberlakukan UU Paten yang baru.

Setelah merdeka, Indonesia baru memiliki dan memberlakukan UU Paten No. 6 Tahun $1989^{2}$ yang disahkan pada tanggal 1 November 1989 dan mulai efektif diberlakukan sejak tanggal 1 Agustus 1991. UU Paten tersebut kemudian direvisi dengan UU Paten No. 13 Tahun 1997 pada tanggal 7 Mei $1997^{3}$ sebagai konsekuensi persetujuan pembentukan Organisasi Perdagangan Dunia. ${ }^{4}$ Selama kurang lebih 7 tahun memberlakukan UU Paten, Kantor Paten Indonesia telah menerima permintaan paten sebanyak 21.761(dua puluh satu ribu tujuh ratus enam puluh satu) hingga akhir Maret $1998^{5}$ dan jumlah permintaan paten dari dalam negeri hanya sekitar 3\% (tiga persen) dari seluruh permintaan paten tersebut.

Dengan memperhatikan jumlah permintaan paten yang diajukan tersebut di atas dan membandingkan permintaan paten yang terjadi di negara-negara maju telah menimbulkan pertanyaan bagaimanakah peranan UU Paten di Indonesia dalam upaya meningkatkan kemampuan bangsa Indonesia di bidang teknologi paten. Selain itu, bagaimanakah agar UU Paten dan peranan teknologi paten mampu meningkatkan pembangunan industri di tanah air, dapat memberikan kontribusi terhadap devisa negara dan bukan sebaliknya, serta mensejajarkan posisi Indonesia dengan bangsa-bangsa lain di bidang tersebut khususnya dengan negara-negara industri maju.

Di sisi lain, dengan keikutsertaan Indonesia pada Organisasi Perdagangan Dunia, maka negara ini - sebagai negara berkembang - berkewajiban mengimplementasikan perundang-undangan di bidang Hak Atas Kekayaan Intelektual (Intellectual Property Rights) khususnya paten secara efektif yang di mulai awal Januari 2000. Padahal dalam kondisi perekonomian dan industri yang sedang terpuruk seperti sekarang ini, perkembangan pelanggaran paten, misalnya; $\mathrm{d} i$ bidang industri farmasi dan otomotif akan banyak terjadi, sehingga mengakibatkan terjadinya konflik antara negara-negara industri maju dan Indonesia. Bisa tejadi konflik itu akan menempatkan Indonesia dalam posisi yang tidak menguntungkan karena dihadapkan pada Organisasi Perdagangan Dunia. Sehingga konflik yang terjadi itu akan berpengaruh terhadap posisi perdagangan Internasional Indonesia. Bagaimanapun, hal itu akan dapat dihindari apabila pelaksanaan UU paten dilaksanakan secara efektif. Persoalannya, apakah Indonesia telah siap melaksanakan perundang-undangan paten secara efektif?

${ }^{2}$ Adanya perbedaan waktu pengesahan dan mulai diberlakukannya secara efektif.UU Paten itu adalah untuk memberikan kesempatan bagi Kantor Paten untuk mempersiapkan perangkat keras, sumber daya manusianya agar pada tanggal yang telah ditentukan dapat mulai menerima permintaan paten secara efektif.

${ }^{3}$ Revisi UU Paten itu dilakukan bersamaan dengan revisi UU Hak Cipta No. 12 Tahun 1997, dan UU Merek No. 14 Tahun 1997 serta ratifikasi beberapa konvensi internasional yaitu; Konvensi Paris, Patent Cooperation Treaty, Trademark Law Treaty, Bern Convention, dan WIPO Copyright Treaty.

${ }^{4}$ Ditetapkan dengan UU No. 7 Tahun 1994, yang kemudian diikuti dengan beberapa revisi UU di bidang HAKI. Lihat supra note nomor 3.

'Data diperoleh dari Kantor Paten, Ditjen HCPM, Departemen Kehakiman. 


\section{Sengketa Paten di Negara-Negara Maju}

Jika diperhatikan era sebelum tahun sembilan puluhan, masalah spionase yang berpangkal pada masalah politik antara negaranegara liberal dan sosialis, antara negaranegara 'Barat dan Eropa Timur memegang peranan yang sangat dominan. Pada saat itu, dapat dikatakan, masalah spionase di bidang teknologi untuk kepentingan dominasi ekonomi terutama spionase teknologi yang dilakukan oleh pihak swasta belum tampak begitu dominan. Akan tetapi, dengan berakhirnya dominasi negara sosialis terutama dengan runtuhnya Uni Soviet, maka Amerika Serikat, Jepang dan Negara-negara di Eropa Barat terutama Inggris, Perancis, dan Jerman memegang peranan yang dominan tidak hanya di bidang politik, tetapi juga di bidang teknologi dan ekonomi. Pada era ini peningkatan spionase terjadi pada bidang teknologi dan kreasi-kreasi yang mengacu pada persaingan global dan mengarah pada peningkatan kemampuan ekonomi serta kesejahteraan -masyarakat.

Di bidang teknologi, dalam buku The Patent Wars, the Battle to Own the World's Technologys karangan Fred Warshoefsky diramalkan bahwa pada saat kini perang global yang terkeji dalam upaya pendominasian ekonomi adalah mengenai hak atas kekayaan intelektual atau hak milik intelektual. Jika pada saat lampau, tujuan utama negara-negara yang saling bertikai adalah untuk mengontrol jalur-jalur perdagangan dan bahan mentah.
Namun, pada saat kini dan masa mendatang Indonesia akan bertikai untuk hak-hak eksklusif terhadap ide-ide, inovasi-inovasi, kreasikreasi dan penemuan-penemuan. Kancah peperangan yang tanpa mengeluarkan tetesan darah ini bukanlah di medan perang melainkan di forum Pengadilan, di mana jutaan dolar akan direnggut atau lenyap melalui litigasi paten. Sebagai contoh pada tanggal $10 \mathrm{Fe}$ bruari 1992 Honeywell Inc. suatu badan hukum Amerika Serikat yang membuat peralatan kontrol elektronik harus menerima imbalan kompensasi sebesar US $\$ 127,000,000.00$ (seratus dua puluh tujuh juta dolar) lebih dari Minolta, badan hukum Jepang pembuat kamera. Di sisi lain, Litton Industry pembuat ring laser gyroscope telah mengajukan tuntutan sebesar US $\$ 3,6,000,000,000.00$ (tiga koma enam milyar dolar) kepada Höneywell dan bermaksud menuntut Pemerintah Amerika Serikat sebesar US $\$ 1,000,000,000.00$ (satu milyar dolar). sebagai tambahan royalti paten tersebut yang digunakan oleh pesawat militer. Selain itu, Nintendo Amerika salah satu pembuat video-game terbesar dari Jepang telah kehilangan lebih dari US $\$ 2,000,000,000.00$ (dua milyar dolar) selama dua tahun pada awal tahun 90-an.

Belum lama ini, Pemerintah Amerika Serikat membayar US $\$ 8,000,000.00$ (delapan juta dolar) kepada AIL SYSTEM INC. sebagai upaya penyelesaian sengketa pelanggaran paten yang dilakukan oleh pemerintah Amerika Serikat terhadap US PATENT No. 3.824.5957

'Lebih jauh lihat. Fred Warshoefsky. 1994. The Patent Wars, the Battle to Own the World's Technology. John Wiley \& Sons. Inc.

${ }^{7}$ World Patent \& Trademark News. Vol. 1 No. 1. March 1998. HIm. 9. 
untuk "a high-tech system that determines the direction or arrival of an enemy signal."

Memperhatikan kasus-kasus di atas, memberi kesan bahwa sengketa paten antara pemilik/pemegang paten dengan pelanggar paten merupakan suatu hal yang dapat terjadi, dan pelaksanaan perundang-undangan paten dapat berjalan efektif di negara-negara tersebut. Apakah penyelesaian sengketa itu diselesaikan di dalam atau di luar badan peradilan, misalnya: dengan melakukan perdamaian.

\section{Data-data Permintaan Paten}

Dalam memikirkan inovasi, maka alam pikiran harus mengacu pada pengembangan di bidang teknologi. Dalam pengembangan teknologi, 'maka alam pikiran juga harus mengarah pada teknologi yang dapat dipatenkan (patented technology) dan bukan mengarah pada teknologi usang yang nilai ekonomisnya telah berkurang, atau bahkan nilai ekonomisnya telah hilang sama sekali. Dengan mengarahkan alam pikiran dan intelektual pada teknologi yang dipatenkan, maka akan memberikan nilai tambah ekonomi yang besar tidak hanya kepada inovator atau inventor itu sendiri tetapi juga bagi lembaganya tempat ia bekerja dan juga nilai positif bagi negaranya. Karena dengan teknologi paten itu, sang inovator dan lembaganya akan memperoleh hak-hak eksklusif, hak-hak ekonomi berupa royalti yang akan diperolehnya jika inovasi yang berupa teknologi paten itu dilisensikan kepada pihak lain. Lebih dari itu, inovator yang mampu menjadi seorang inventor yang berhak atas paten akan mampu mengatasi persaingan global yang akan dihadapi pada abad XXI mendatang. Bahkan, teknologi paten akan mampu memberikan tambahan devisa negara apabila pemilik teknologi paten nasional mengadakan perjanjian lisensi paten dengan pihak pemakai yang berasal dari luar negeri. Karena dengan adanya perjanjian lisensi itu, maka pemilik teknologi paten akan memperoleh imbalan berupa royalti dari pihak asing. Begitu pula sebaliknya, apabila para pengusaha di Indonesia hanya menjadi penerima lisensi atas teknologi paten yang berasal dari luar negeri, maka akan cukup besar royalti yang dibayar sehingga akan menguras devisa negara. Sangat disayangkan, hingga sekarang belum. dapat diketahui berapa banyak devisa yang dibayar dan diterima dari pemakaian teknologi paten itu. Tidak ada satu pun departemen atau lembaga pemerintah, apakah itu departemen Perindustrian dan Perdagangan (Deperindag), Badan Koordinasi Penanaman Modal (BKPM) yang merupakan "gerbang" masuknya investasi asing dan nasional, maupun Biro Pusat Statistika (BPS) yang mencatat jumlah pengeluaran dan penerimaan devisa dari pemanfaatan teknologi paten. Padahal, selayaknya BKPM atau Deperindag mampu melakukan pendataan terhadap jumlah devisa tersebut.

Lalu, bagaimanakah sebenamya kondisi teknologi yang dipatenkan yang diajukan permintaan patennya ke berbagai Kantor Paten? Dengan memperhatikan pada data permintaan paten di Kantor Paten Eropa (European Patent Office) $)^{8}$ dapat dengan mudah diketahui bagaimana peranan negara-negara industri maju, misalnya Amerika Serikat,

\footnotetext{
'Lihat Tabel 1
} 
Jerman, Jepang, Prancis, dan Inggris dalam mengajukan permintaan paten di Kantor Paten Eropa menunjukan peranan yang begitu dominan. Lebih dari $70 \%$ (tujuh puluh persen) permintaan paten pada kantor paten tersebut dikuasai oleh lima negara industri maju tersebut. Tiga negara pertama yaitu Amerika Serikat, Jerman, dan Jepang telah menguasai sekitar $60 \%$ (enam puluh persen) permintaan paten. Sementara permintaan paten dari lndonesia, upaya pengajuan permintaan paten di Kantor Paten itu hanya 0,01\% (nol koma nol satu persen) atau 4 buah permintaan paten pada tahun 1993 diduga, jumlah permintaan paten melalui Kantor Paten Eropa akan semakin sedikit karena kondisi perekonomian yang memburuk saat ini.

Kemudian, jika kita cermati pula permintaan paten yang terjadi pada Kantor Paten Jepang ${ }^{9}$ maka upaya bangsa Indonesia untuk menyamainya tentu memerlukan waktu yang cukup lama apabila tidak dilakukan perubahan-perubahan dan peningkatan kemampuan sumber daya manusianya. Dengan merujuk pada data permintaan paten di Jepang tahun 1992-1995 yang rata-ratanya pertahun 300.000 (tiga ratus ribu) permintaan paten, dan jika dihitung dengan jumlah penduduk Jepang sekitar 120.000 .000 (seratus dua puluh juta) jiwa maka setiap 400 (empat ratus) orang Jepang akan mengajukan 1 permintaan paten. Jumlah permintaan paten di Jepang yang dilakukan oleh pihak Jepang mencakup lebih dari $90 \%$ (sembilan puluh persen) dari seluruh permintaan paten yang diajukan di Kantor Paten tersebut. Dengan berpikir positif dan mengesampingkan adanya kemungkinan pencurian atau peniruan teknologi paten pihak lain, menimbulkan pertanyaan bagaimanakah masyarakat Jepang itu digugah agar setiap inovasi, penemuan atau invention di bidang teknologinya diajukan patennya pada Kantor Paten di negara tesebut? Hal ini tidak lain karena mereka mengharapkan inovasi atau penemuan itu dilindungi oleh UU Paten yang berlaku di negara tersebut. Mereka ingin memetik manfaat ekonomi dengan pengajuannya itu. Karena dengan memiliki paten atas suatu teknologi tertentu mereka tidak perlu melakukan perjanjian lisensi paten, dan membayar royalti kepada pemilik/pemegang paten di dalam negeri sehingga pengeluaran devisa atas teknologi paten dapat dikurangi.

Lalu bagaimanakah keadaan permintaan paten yang diajukan melalui Kantor Paten di Indonesia? Sekali lagi perlu disadari bahwa permintaan paten yang diajukan oleh Amerika Serikat dan Jepang mencapai 50,07\% (lima puluh koma nol tujuh persen) atau ekuivalen dengan 10.897 (sepuluh ribu delapan ratus sembilan puluh tujuh) permintaan paten dari jumlah sebanyak 21.761 (dua puluh satu ribu tujuh ratus enam puluh satu) permintaan paten. Perlu diakui bahwa permintaan paten dari inovator atau inventor Indonesia hanya mencapai $3,15 \%$ (tiga koma lima belas persen) atau 685 (enam ratus delapan puluh lima) permintaan paten. Data itu hanya mengalami peningkatan sedikit jika dibandingkan déngan akhir tahun 1995 yang mencapai 2,29\% (dua koma dua puluh sembila persen) atau sebanyak 384 (tiga ratus delapan puluh empat) permintaan paten. Data permintaan yang diajukan oleh inventor Indonesia itu terdiri atas

'Lihat Tabel 2 
paten biasa dan paten sederhana yang masing-masing berjumlah 367 (tiga ratus enam puluh tujuh) permintaan paten atau $1,69 \%$ (satu koma enam puluh sembilan persen) dan 317 (tiga ratus tujuh belas) permintaan paten sederhana atau 1,46\% (satu koma empat puluh enam persen). ${ }^{10}$

Dengan sedikitnya jumlah permintaan paten, menimbulkan pertanyaan yaitu; apakah hal itu merupakan salah satu indikasi rendahnya kemampuan bangsa Indonesia untuk melakukan penemuan-penemuan, inovasi-. inovasi yang berhak atas paten? Ataukah, masih begitu rendahnya tingkat kesadaran para inventor akan perlunya mempatenkan atas setiap penemuan di bidang teknologi? Ataukah karena faktor-faktor kemampuan ekonomis saja? Tapi, di sisi lain juga menimbulkan pertanyaan, apakah benar bangsa Indonesia, para peneliti, para akademisi, para pengusaha, dan pemuda-pemuda Indonesia cuma mampu sebatas ucapan saja dalam mengembangkan teknologi tertentu, tanpa perlu memikirkan pengembangan teknologi itu sampai mendapatkan hak paten atas penemuannya itu? Gaung dan gema agar ditingkatkan kemampuan teknologi bangsa, menumbuhkembangkan riset-riset unggulan, rasanya telah lama didengar. Tetapi kenapa, jumlah permintaan paten yang diajukan oleh inventor, menjadi inventor yang mampu menemukan teknologi yang berhak atas paten? Ataukah, karena para inventor, para peneliti, atau pemuda inventor bangsa Indonesia tidak tahu keberadaan UU Paten? Tidak tahu, bahwa setiap inovasi atau invention di bidang teknologi itu perlu diajukan permintaan paten- nya agar mendapat perlindungan hukum. Satu hal yang utama adalah agar inovasi itu mempunyai nilai ekonomis bagi inventomya, dan juga agar dapat meningkatkan kesejahteraannya. Karena setiap inovasi yang berhak atas paten akan mempunyai nilai ekonomis yang tinggi apabila diterapkan.

Selama ini telah didengar dan bahkan disaksikan lomba ataupun pameran yang berkaitan dengan bidang teknologi, atau karyakarya ilmiah. Mereka pamerkan semua inovasi, invention atau penemuan-penemuannya. Dan mereka begitu gembira Indonesia mendapatkan penghargaan secarik kertas dan sejumlah hadiah. Setelah itu, inovasi, invention mereka terlupakan begitu saja oleh inovatornya dan juga para panitia penyelenggaranya. Bangsa Indonesia seolah terlupakan bahwa setiap inovasi atau penemuan di bidang teknologi itu telah memerlukan waktu yang tidak sedikit dan biaya yang tidak murah. Dan tidak disadari bahwa pihak ketiga, para pengusaha baik nasional atau asing yang begitu jeli memanfaatkan kesempatan melakukan spionase dan bahkan telah mencuri inovasi yang dibuat oleh para inventor Indonesia tanpa harus membayar royalti satu rupiah pun. Dan Indonesia tidak bisa berbuat apa pun karena belum mau mengaitkan setiap kegiatan tersebut dengan perlindungan hukumnya, dan tidak mengaitkannya dengan UU Paten.

Selain itu, selama ini telah cukup banyak karya-karya siswa, para insinyur muda bangsa Indonesia yang dikirim untuk melanjutkan tugas belajarnya di manca negara, terutama yang dibiayai oleh negara. Namun, sangat disayangkan tidak banyak para karya siswa

${ }^{10}$ Lihat Tabel 3. 
yang mampu membawa pulang penemuanpenemuan di bidang teknologi yang dapat dipatenkan dan bermanfaat bagi negara Indonesia sendiri. Bahkan yang terjadi, tidak sedikit inovasi-inovasi yang dilakukan oleh pemuda-pemuda Indonesia menjadi milik pihak asing, dimiliki oleh institusi atau lembaga tempat para karya siswa, tampaknya cukup merasa puas pulang ke tanah air hanya dengan membawa gelar master of science atau doktor. Tetapi mereka lupa, bahwa inovasi-inovasi yang mereka lakukan dari penelitian-penelitian yang memakan waktu dan keringat serta uang negara, sebenarnya harus menjadi salah satu kekayaan nasional. Yang dapat menambah peningkatan kesejahteraan dirinya, lembaganya di tanah air dan juga negara. Tetapi, sangat disayangkan tanpa disadari bahwa penemuan-penemuan dari karya-karya siswa Indonesia justru telah menambah kekayaan institusi atau lembaga tempat mereka menimba ilmu di luar negeri. Kenapa hal ini bisa terjadi? Karena mereka tidak mengerti bahwa setiap inovasi, penemuan yang mereka lakukan berhak atas paten. Dan berhak memperoleh perlindungan hukum. Dan berhak pula atas royalti apabila pihak lain memanfaatkannya.

Jika dihitung jumlah para karya siswa Indonesia yang menjadi karya siswa di manca negara yang telah mencapai ribuan orang, maka seharusnya jumlah permintaan paten yang diajukan oleh karya siswa Indonesia haruslah juga mencapai ribuan permintaan paten dan bukan dengan jumlah seperti pada saat ini.
Kemudian, hingga saat kini masih cukup banyak perguruan tinggi dan lembaga-lembaga di bidang penelitian dan pengembangan yang belum memahami akan pentingnya UU Paten. Dan masih sedikit para inventor dan inovator Indonesia yang meneruskan inovasi atau penemuannya itu untuk diajukan ke Kantor.Paten. Padahal, jika setiap perguruan tinggi mampu mendapatkan paten atas penemuan yang dilakukannya dan layak jual maka perguruan tinggi itu akan mampu. menjadi perguruân tinggi yang swadiri.

Dengan demikian, menjadi jelas bahwa orang Indonesia bukanlah tidak mampu melakukan inovasi, penemuan-penemuan-di bidang teknologi yang berhak atas paten. Tetapi, yang terjadi adalah belum banyak inovator atau inventor nasional yang memahami pentingnya perlindungan hukum atas inovasi mereka. Belum banyak-yang-mendalami akan pentingnya UU Paten bagi inovasi mereka.

\section{Data Ekspor Migas dan Non Migas}

Selama ini data ekspor nasional Indonesia," secara makro, dibagi dua bagian yaitu ekspor migas dan ekspor non-migas, dari data ekspor non-migas per Juni 1996 terlihat adanya ekspor bidang industri sebesar 29,3 milyar dolar dan industri lainnya 12,3 milyar dolar. Namun, dari data tersebut tidak dijelaskan apakah ekspor di bidang industri dan industri lainnya itu ternasuk royalti dari paten atau hak cipta (misalnya:- royalti dari industri rekaman) termasuk di dalam perhitungan

\footnotetext{
"Lihat Tabel 4.
} 
tersebut atau tidak? Seandainya termasuk, untuk industri yang bagaimanakah itu?

Menilai data ekspor Amerika Serikat pada tahun 1946 dinyatakan bahwa 10\% (sepuluh persen) devisa ekspor yang diperoleh adalah dari hak kekayaan intelektual, misalnya: royalti paten, hak cipta dan sebagainya. Pada tahun 1986 meningkat menjadi 37\% (tiga puluh tujuh persen) dari total ekspor. ${ }^{12}$ Begitu pula Inggris dan Jepang telah mengaitkan data ekspor mereka dengan devisa yang diperoleh dari royalti atas lisensi paten, lisensi hak cipta atau lisensi di bidang teknologi lainnya. Dengan membandingkan pola ekspor-impor negara-negara tersebut akan menampakkan kejelasan bahwa hak kekayaan intelektual telah menjadi bagian dart strategi ekspor negara-negara industri maju. Mengharapkan Indonesia mampu mengembangkan devisa dari ekspor HAKI mungkin masih terlalu jauh apabila pola pikir aparat pada para pengusaha Indonesia masih seperti saat ini.

Namun demikian, apabila eksportir Indonesia mengekspor produk-produk dengan menggunakan teknologi (paten) tertentu perlu pula memperhatikan kemungkinan adanya kendala yang terjadi karena adanya konflik dengan paten milik orang lain di negara tujuan ekspor. Jangan sampai ekspor itu menimbulkan kendala pula bagi upaya peningkatan devisa, karena tidak tertutup kemungkinan adanya tindakan-tindakan "mafia HAKI" atau "mafia paten"13 yang akan menghambat ekspor Indonesia ke negara tujuan. Hal itu terjadi, apabila produk yang diekspor dengan meng- gunakan teknologi (paten) pihak lain. Pihak yang memiliki teknologi (paten) itu melakukan tuntutan terhadap eksportir Indonesia. Akibatnya, bisa terjadi eksportir Indonesia hanya menerima pesanan memproduksi produk tertentu dengan teknologi (paten) yang telah ditentukan oleh importir tanpa memeriksa kembali apakah ia berhak atas teknologi (paten) tersebut. Ketika produk itu sampai di negara tujuan ekspor, ternyata pemilik/pemegang paten yang sebenarnya melaporkan dugaan adanya pelanggaran paten kepada pihak berwajib sehingga produk itu ditahan di pelabuhan, dan diproses menurut ketentuan hukum di negara tersebut.

Indonesia sebagai negara berkembang, selayaknya harus banyak belajar tentang bagaimana meningkatkan devisa ekspor melalui HAKI khususnya teknologi paten, dan tidak tergantung pada ekspor yang berbasis pada sumber daya alam saja. Karena ekspor yang didasarkan pada HAKI (misalnya paten, merek, hak cipta, semi konduktor) khususnya paten akan mampu memiliki posisi tawar menawar (bargaining position) yang lebih baik dibandingkan dengan ekspor bahan mentah saja, yang kerap kali harganya ditentukan oleh pembeli/importir.

\section{GBHN dan Persetujuan GATT}

Indonesia telah memiliki UU No. 6 Tahun 1989 yang kemudian direvisi dengan UU Paten No. 13 Tahun 1997 pada tanggal 7 Mei 1997. Revisi itu merupakan konsekuensi keikut-

${ }^{12}$ Warshofsky. Op.Cit.HIm. 6.

${ }^{13}$ Insan Budi Maulana. "Patent Mafia atau Mafia Paten?". Kompas. 28 April 1997. Lebih lanjut Henry Koda dan Hiroto Yamamoto. 1995. Senritsu no Patento Mafia. 
sertaan Indonesia pada Putaran Uruguay yang telah ditandatangani di Maroko pada tanggal 15 April 1994, dan UU No. 7 Tahun 1994 tentang Perjanjian Pengesahan Organisasi Perdagangan Dunia. Sesungguhnya yang mengalami revisi tidak hanya UU Paten tetapi juga UU Hak Cipta No. 7 Tahun 1987 yang telah direvisi dengan UU No. 12 Tahun 1997 dan atau UU Merek No. 19 Tahun 1992 dengan UU Merek No. 14 Tahun 1997. Selain itu Indonesia masih harus menetapkan beberapa UU lain misalnya: UU Semi Konduktor, UU Rahasia Dagang, dan UU Persaingan Curang.

Dalam GBHN 1988 pun, kita telah mengupayakan untuk meningkatkan perlindungan hukum terhadap hak atas kekayaan intelektual, di antaranya adalah paten dan hak cipta yang berkaitan dengan inovasi atau penemuan di bidang teknologi dan kreasi-kreasi di bidang ilmu, seni dan sastra. Dalam GBHN itu dinyatakan "Demikian pula perlu dimantapkan jaminan hak cipta dan hak-hak intelektual lainnya serta pemberian penghargaan bagi hasil penemuan dan karya ilmiah. Dalam berbagai kegiatan tersebut perlu dikembangkan peran serta dunia usaha".

Dengan telah ditetapkannya $U U$ dan persetujuan tersebut di atas, mau tidak mau Indonesia harus mempersiapkan dirinya dalam era globalisasi mendatang agar dapat meningkatkan kemampuan berinovasi dan berkreasi bagi tercapainya bangsa yang jaya.

\section{Penemuan yang Dapat Dipatenkan}

Suatu penemuan, kreasi atau inovasi di bidang teknologi dapat dipatenkan apabila penemuan itu memenuhi tiga unsur yaitu: 1) penemuan itu merupakan penemuan yang baru (novelty) artinya penemuan itu belum pernah dipublikasikan, atau belum pernah ada sebelumnya; 2) penemuan itu memiliki langkah inventif (inventive steps), memiliki proses atau tahapan-tahapan dan tidak tiba-tiba menjadi begitu saja; dan 3) penemuan itu dapat diterapkan di bidang industri (applicable in industry) atau useful (berguna). Namun, tidak selalu penemuan yang memenuhi ketiga unsur tersebut berhak atas paten karena penemuan itu tidak dapat dipatenkan, yaitu:

1. apabila bertentangan dengan moral termasuk moralitas agama, ketertiban umum, atau kesusilaan, misalnya: pengkloningan domba bisa ditolak penemuan patennya apabila penemuan itu bertentangan dengan agama; begitu juga teknologi nuklir yang berkaitan dengan militer tidak dapat dipatenkan di Jepang, tetapi jika berkaitan dengan pertanian dapat dipatenkan;

2. apabila penemuan itu merupakan metode pemeriksaan, perawatan, pengobatan, dan pembedahan yang diterapkan teihadap manusia dan hewan, tetapi tidak menjangkau produk apa pun yang digunakan, atau berkaitan dengan metode tersebut, misalnya metode "terkun" untuk pengobatan;

3. apabila penemuan itu merupakan teori dan metode di bidang ilmu pengetahuan dan matematika, misalnya program komputer. Di negara lain, misalnya Amerika Serikat atau Jepang, program komputer dapat dipatenkan.

Di luar ketiga hal tersebut di atas, menurut UU Paten No. 13 Tahun 1997 setiap penemuan dapat dipatenkan termasuk di bidang varitas baru tanaman atau hewan, atau tentang proses apa pun yang dapat digunakan untuk pembiakan tanaman atau hewan beserta 
hasilnya, misalnya: tanaman padi yang dapat menghasilkan sekian ton untuk per hektar, atau dapat berkembang untuk waktu lebih cepat. Selain itu, juga dapat dipatenkan penemuan tentang proses atau hasil produksi makanan dan minuman, termasuk hasil produk berupa bahan yang dibuat melalui proses kimia dengan tujuan untuk membuat makanan dan minuman guna dikonsumsi manusia dan atau hewan, misalnya: tempe yang dikembangkan sehingga mampu bertahan lama dan mencegah kanker.

\section{Kebangkitan Teknologi: Reformasi Penulisan Skripsi \& Penelitian}

Indonesia telah merayakan era kebangkitan teknologi ketiga. Selayaknya, kebangkitan teknologi itu diindikasikan pada beberapa banyak inovasi atau penemuan yang diajukan permintaan patennya. Tidak hanya diajukan pada Kantor Paten di Indonesia tetapi juga kantor paten di negara lain di mana kompetitor itu berada. Berapa banyak devisa negara diperoleh dari royalti atas lisensi teknologi paten tersebut. Tanpa diarahkan inovasi-inovasi di bidang teknologi paten bangsa Indonesia yang diperuntukkan bagi peningkatan komoditas ekspor nasional, maka janganlah bermimpi akan memenangkan era persaingan global yang akan dihadapi beberapa tahun mendatang. Karena, tanpa memikirkan hal tersebut, Indonesia hanya menjadi pasar bagi inovasi dan penemuan-penemuan bangsa lain. Indonesia tidak akan menjadi subjek melainkan objek bangsa lain. Indonesia tidak akan menjadi gelombang tetapi menjadi buih yang terombang-ambing.

Untuk menghadapi kondisi di atas, maka perlu dilakukan reformasi di kalangan peneliti di perguruan tinggi dan para peneliti di lembaga-lembaga lain yang secara potensial lebih mampu menghasilkan penemuan-penemuan di bidang teknologi paten. Cara yang dapat dilakukan adalah dengan mengubah pola pikir peneliti yang selama ini hanya menghabiskan biaya proyek atau penelitian pesanan diganti menjadi peneliti yang berpotensi mendapatkan paten, dan memiliki nilai ekonomis yang tinggi. Selain itu, jika selama ini para mahasiswa, misalnya: Fakultas Tehnik, Pertanian, Kedokteran, serta Fakultas Matematika dan Pengetahuan Alam yang diharuskan membuat tugas akhir berupa skripsi yang didasarkan pada penelitiannya diubah pada penelitian skripsi itu. Mereka tidak hanya sekedar dan diharapkan menulis skripsi serta ijazah kesarjanaannya setelah skripsi itu selesai ditulis, tetapi bentuk dan pola penulisan skripsi itu diubah menjadi "berbentuk deskripsi" yang uraian-uraiannya merupakan penemuan-penemuan yang memungkinkan berhak atas paten. Jika diasumsikan setiap tahun dapat 50 (lima puluh) orang mahasiswa yang membuat tugas akhir untuk memperoleh kesarjanaan, maka jika di Universitas itu terdapat 4 (empat) Fakultas yaitu: Pertanian, Kedokteran, Tehnik, Mipa maka terdapat sekitar 200 (dua ratus) peneliti yang potensial memperoleh paten. Jika di seluruh Indonesia terdapat 27 (dua puluh tujuh) Universitas $\mathrm{Ne}$ geri (dengan perhitungan kasar) maka terdapat 5400 (lima ribu empat ratus) permintaan paten. Jumlah ini dengan mengesampingkan penelitian-penelitian dosen, peneliti pada lembaga litbang, para pengusaha, atau individu lainnya. Dengan jumlah itu, prosentasi permintaan paten akan didominasi para inventor nasional. Jika dari jumlah itu, diasumsikan yang mendapat paten sekitar $5 \%$ (lima persen) saja 
(dalam realitas di Indonesia sekitar $40 \%$ (empat puluh persen) yang diajukan berhak atas paten) yang berhak atas paten, maka sekitar 170 (seratus tujuh puluh) paten diterima oleh inventor asal Indonesia. Kemudian, jika paten itu ditawarkan kepada para peminat di bidang industri baik pertanian, mesin, farmasi, dan sebagainya, maka akan dapat menggairahkan para peneliti lainnya melakukan penelitian. Bagi industri, untuk sementara waktu, tidak perlu harus mendirikan lembaga riset dan penelitian sendiri tetapi cukup bekerja sama dengan perguruan tinggi yang berpotensi menghasilkan penemuan-penemuan paten. Sehingga diharapkan dapat menghemat biaya.

Dalam melakukan penelitian yang memungkinkan dapat dipatenkan, para peneliti dapat mencari "jalan pintas" dengan membaca informasi permintaan paten yang sedang atau telah diberikan baik melalui internet atau Berita Resmi Paten yang diterbitkan oleh Kantor Paten Indonesia atau asing, kemudian meneliti, mengembangkan, dan melakukan pengembangan atau perbaikan-perbaikan atas kékurangan-kekurangan, kelemahankelemahan dari prior art (penemuan sebelumnya). Cara seperti itu jauh lebih cepat, sederhana, tidak membutuhkan biaya yang terlalu besar dan tidak perlu meneliti dari awal. Langkah penelitian seperti itu, merupakan hal yang sering dilakukan oleh para inventor atau para peneliti di negara-negara maju.

Dengan melakukan reformasi atau penulisan skripsi, dan pola pikir melakukan penelitian-penelitian di bidang teknologi, termasuk pameran di bidang teknologi, maka slogan kebangkitan teknologi nasional akan dapat dicapai.

Belum lama ini telah disiarkan melalui media cetak LIPI mulai menyadari akan pentingnya paten, ${ }^{14}$ dan BPPT ${ }^{15}$ telah mulai memikirkan upaya-upaya pembagian royalti dengan menentukan prosentasi pembagiannya terhadap hasil penelitian yang berhak atas paten, masing-masing kepada para peneliti atau inventor, lembaga penelitian yang membiayai dan badan tersebut. Jika memperhatikan jumlah prosentasi besarnya royalti maka hal itu dapat dianggap memadai. Sehingga, seharusnya dapat memacu motivasi para peneliti untuk mengembangkan penemuannya agar dapat diberikan paten. Meskipun hal itu terasa terlambat, namun dapat diharapkan memacu pula lembaga-lembaga lain di perguruan tinggi melakukan hal yang sama. Jika hal itu dapat dimasyarakatkan, maka diperkirakan jumlah permintaan paten di Indonesia dapat meningkat. Tentu saja, diharapkan permintaan paten itu juga harus mempertimbangkan aspek pasar dengan memperhatikan jumlah konsumen, atau pengguna, dan aspek laba dengan memperhatikan berupa keuntungan yang dapat diperoleh. Di samping juga perlu diperhatikan aspek kompetisi, dengan memperhatikan kemungkinan pihak lain, misalnya pihak asing akan mengajukan penemuan yang serupa dan bila itu diterima, sementara penemuan itu sangat dibutuhkan karena memang dibutuhkan, maka akan mengakibatkan para pengusaha nasional, atau masyarakat Indonesia membutuhkannya dan membayar royalti yang tinggi sehingga mengurangi de-

\footnotetext{
${ }^{14}$ Kompas. Tak Acuhkan Paten, Peneliti Bisa Jadi Pihak Merugi. 19 Agustus 1998.

${ }^{15}$ Bisnis Indonesia. BPPT Usul PNBP Hasil Karya Intelektual Gunakan Pos Audit. 20 Agustus 19908.
} 
visa, dan bukan sebaliknya, jika inventor na- dapat membasmi virus Aids, atau paru. Alat sional mampu mendapatkan paten tersebut tranfusi atau pencuci darah penderita ginjal maka diharapkan, tidak hanya dapat meng- yang murah dan aman, dan sebagainya. hemat devisa tetapi juga memperoleh devisa Produk-produk atau proses-proses penemuan dari penggunaan paten tersebut. Umpamanya, paten seperti itu akan sangat diharapkan, dan penemuan-penemuan di bidang medis yang mempunyai nilai ekonomi yang tinggi.

Tabel 1

Permintaan Paten di Kantor Paten Eropa (EPO)

Tahun 1993

\begin{tabular}{|c|c|c|c|c|c|}
\hline No & Negara & Permintaan & $\%$ & Yang Menerima & $\%$ \\
\hline 1 & Amerika Serikat & 16.682 & 29,28 & 8.531 & 23,27 \\
\hline 2 & Jerman & 10.999 & 19,31 & 8.736 & 23,83 \\
\hline 3 & Jepang & 10.285 & 18,05 & 7.518 & 20,50 \\
\hline 4. & Perancis & 4.331 & 7,60 & 3.355 & 9,15 \\
\hline 5 & inggris & 3.113 & 5,46 & 1.872 & 5,11 \\
\hline 6 & Indonesia & 4 & 0,01 & - & - \\
\hline 7 & Lain-lain & 11.552 & 20,29 & 6.655 & 19 \\
\hline & Total & 56.966 & 100 & $36.667^{\circ}$ & 100 \\
\hline
\end{tabular}

Sumber: EPO 
Insan Budi Maulana. Penerapan Paten Sejak UU No. 6 Tahun 1989 ...

Tabel 2

Permintaan Paten di Kantor Paten Jepang

\begin{tabular}{|c|c|c|c|c|c|}
\hline Tahun & Jepang & $\%$ & Asing & $\%$ & Jumlah \\
\hline 1992 & 338.019 & 90,9, & 9,176 & 9,1 & 371.894 \\
1993 & 332.345 & 90,7 & 10.415 & 9,3 & 366.486 \\
1994 & 319.938 & 90,6 & 11.423 & 9,4 & 353.301 \\
1995 & 334.612 & 90,6 & 13.320 & 9,4 & 369.215 \\
\hline
\end{tabular}

Tabel 3

Pertumbuhan dan Komposisi Ekspor Nonmigas

\begin{tabular}{|l|c|c|c|}
\hline \multicolumn{1}{|c|}{ Sektor } & $\begin{array}{c}\text { Nilai 1995 } \\
\text { (US\$ Milyar) }\end{array}$ & $\begin{array}{c}1994 \\
(\%)\end{array}$ & $\begin{array}{c}1995 \\
(\%)\end{array}$ \\
\hline \multicolumn{1}{|c|}{ Total Ekspor Nonmigas } & 35,0 & 12,1 & 15,1 \\
\hline Pertambangan & 2,7 & 23,6 & 48,9 \\
Pertanian & 2,9 & 22,7 & 2,5 \\
Industri & 29,3 & 10,3 & 14,1 \\
Kayu Olahan & 5,0 & $-5,7$ & $-3,9$ \\
* Kayu Lapis & 3,5 & $-12,0$ & $-6,8$ \\
*. Lainnya & 1,5 & 15,1 & 3,7 \\
Biji Logam & 1,8 & 19,4 & 40,0 \\
Tekstil & 6,2 & $-6,2$ & 7,0 \\
* Pakaian Jadi & 3,4 & $-8,1$ & 5,0 \\
* Pabrik Tenun & 1,6 & $-16,7$ & 4,5 \\
- Lainnya & 1,2 & 23,9 & 16,4 \\
Pengolahan Karet & 2,2 & 30,9 & 57,5 \\
Pengolahan Makanan & 0,8 & 10,1 & 0,7 \\
Kertas & 1,0 & 34,1 & 50,7 \\
Industri lainnya & 12,3 & 28,2 & 16,7 \\
\hline & & & \\
\hline
\end{tabular}

Sumber: Biro Pusat Statistik (BPS) dan Bank Dunia, Juni 1996 
Tabel' 4

Jumlah Permintaan Paten di Kantor Paten Indonesia

1 Agustus 1991-31 Maret 1998

\begin{tabular}{|c|c|c|c|c|c|c|c|c|c|c|c|c|c|c|}
\hline \multirow[t]{2}{*}{ No } & \multicolumn{2}{|c|}{ Negara } & \multirow[t]{2}{*}{1991} & \multirow[t]{2}{*}{1992} & \multirow[t]{2}{*}{1993} & \multirow[t]{2}{*}{1994} & \multirow[t]{2}{*}{1995} & \multirow{2}{*}{1996} & \multirow[t]{2}{*}{1997} & \multicolumn{4}{|c|}{1998} & \multirow[t]{2}{*}{ Jumlah } \\
\hline & & & & & & & & & & 1 & 2 & 3 & 4 & \\
\hline 1 & Amerika & us & 395 & 1440 & 738 & 774 & 901 & 1247 & $\uparrow 219$ & 29 & 43 & 51 & 4 & 6837 \\
\hline 2 & Indonesią & D & 52 & 80 & 68 & 63 & 121 & 99 & 158 & 7 & 19 & 26 & - & 685 \\
\hline 3 & Inggris & GB & 151 & 248 & 150 & 189 & 178 & 213 & 161 & 41 & 54 & 52 & - & 1308 \\
\hline 4 & Jepang & JP & 172 & 666 & 267 & 400 & 592 & 889 & 927 & 14 & 15 & 16 & - & 4060 \\
\hline 5 & Jerman & $D E$ & 131. & 221 & 170 & 189 & 285 & 414 & 408 & 3 & 9 & 3 & - & 1863 \\
\hline 6 & Perancis & FR & 79 & 285 & 58 & 88 & 112 & 151 & 133 & 37 & 38 & 40 & - & 921 \\
\hline 7 & Lain-lain & & 359 & 1087 & 689 & 723 & 827 & 1119 & 1174 & 37 & 38 & 40. & - & 15674 \\
\hline & Jumah, & & 1336 & 4027 & 2140 & 2426 & 3007 & 4132 & 4178 & 139 & 176 & 200 & & 21761 \\
\hline
\end{tabular}

Sumber dari Kantor Paten DITJEN HCPM Departemen Kehakiman, Tanggerang.

Tabel 5

Jumlah Permintaan Paten

Per 31 Maret 1998

\begin{tabular}{|c|c|c|c|c|c|}
\hline \multirow{2}{*}{ Tahun/Bulan } & \multicolumn{2}{|c|}{ Paten } & \multicolumn{2}{|c|}{ - Paten Sederhana } & \multirow{2}{*}{ Jumlah } \\
\hline & Dalam & Luar & Dalam & Luar & \\
\hline $\begin{array}{l}1991 \\
1992 \\
1993 \text { : } \\
1994 \\
1995 \\
1996 \\
1997 \\
1998\end{array}$ & $\begin{array}{l}34 \\
67 \\
38 \\
29 \\
. \quad 61 \\
\cdot \quad 40 \\
79 \\
5 \quad 19\end{array}$ & $\begin{array}{l}1280 \\
3905 \\
2031 \\
2305 \\
2813 \\
3957 \\
3939 \\
462\end{array}$ & $\begin{array}{l}19 \\
12 \\
28 \\
33 \\
61 \\
59 \\
80 \\
25\end{array}$ & $\begin{array}{c}3 \\
43 \\
43 \\
60 \\
71 \\
76 \\
60 \\
9\end{array}$ & $\begin{array}{c}1336 \\
4027 \\
2140 \\
2427 \\
3006 \\
4132 \\
4178 \\
515\end{array}$ \\
\hline $\begin{array}{c}\text { Jumlah " } \\
\%\end{array}$ & $\begin{array}{c}367 \\
, 1,69 \%\end{array}$ & $\begin{array}{c}10692 \\
95,09 \%\end{array}$ & $\begin{array}{c}317 \\
1,46 \%\end{array}$ & $\begin{array}{c}385 \\
1,77 \%\end{array}$ & $\begin{array}{c}21761 \\
100,00 \%\end{array}$ \\
\hline
\end{tabular}

Sumber dari Ditjen HCPM, Departemen Kehakiman 
Tabel 6

Hasil Pemeriksaan Substantif

\begin{tabular}{|c|c|c|c|c|}
\hline \multirow{2}{*}{ Tahun/Bulan } & \multicolumn{3}{|c|}{ Hasil } \\
\cline { 2 - 5 } & \multicolumn{2}{|c|}{ Ditolak } & \multicolumn{2}{c|}{ Diberi } \\
\cline { 2 - 5 } & Paten & Paten Sederhana & Paten & Paten Sederhana \\
\hline \multirow{2}{*}{1992} & - & 2 & - & \\
1993 & 3 & 10 & 2 & - \\
1994 & 6 & 13 & 59 & 16 \\
1995 & 79 & 9 & 390 & 33 \\
1996 & 187 & 28 & 902 & 50 \\
1997 & 177 & 19 & 976 & 45 \\
1998 & 13 & - & 321 & 20 \\
\hline Jumlah & 465 & 81 & 2650 & 220 \\
\hline
\end{tabular}

Sumber dari Ditjen HCPM Departemen Kehakiman

Tabel 7

Ciri-čiri Hak Cipta, Paten, dan Merek

\begin{tabular}{|l|l|l|l|}
\hline \multicolumn{1}{|c|}{ Tipe Perlindungan } & \multicolumn{1}{|c|}{ Hak Cipta } & Paten & Merek Dagang \& Jasa \\
\hline Apa yang dilindungi & $\begin{array}{l}\text { Ciptaan dalam bidang ilmu } \\
\text { pengetahuan, seni, \& sastra, } \\
\text { misibuku, ceramah, senitari, } \\
\text { program komputer, dsb. }\end{array}$ & $\begin{array}{l}\text { Proses atau hasil produksi } \\
\text { ataukombinasi keduanya, } \\
\text { dan benda, alat atau hasil } \\
\text { produksi yang memiliki } \\
\text { kegunaannya praktis. }\end{array}$ & $\begin{array}{l}\text { Kata-kata, nama-nama, } \\
\text { simbol.. }\end{array}$ \\
\hline Kiteria perlindungan & Aslijorisinil & $\begin{array}{l}\text { Kebaruan, memiliki lang- } \\
\text { kah inventif,dandapatdite- } \\
\text { rapkan di bidang industri. }\end{array}$ & $\begin{array}{l}\text { Digunakan untuk mengiden- } \\
\text { tifikasi, dan membedakan } \\
\text { barang dan jasalainnya. }\end{array}$ \\
\hline $\begin{array}{l}\text { Bagaimana mendapatkan } \\
\text { hak }\end{array}$ & Secara otomatis & $\begin{array}{l}\text { Diberi oleh Kantor Paten, } \\
\text { Dijen HCPM berdasarkan } \\
\text { pemohonan }\end{array}$ & $\begin{array}{l}\text { Didaftarkan oleh Kantor } \\
\text { Merek, Dirjen, HCPM } \\
\text { berdasarkan permohonan. }\end{array}$ \\
\hline
\end{tabular}




\begin{tabular}{|l|l|l|l|}
\hline \multicolumn{1}{|c|}{ Tipe Perlindungan } & \multicolumn{1}{|c|}{ Hak Cipta } & Paten & Merek Dagang \& Jasa \\
\hline Jangka waktu & $\begin{array}{l}\text { Seumur hidup }+50 \text { tahun } \\
\text { sesudah mati, kekecualian } \\
\text { tercantum pada Pasal } 27 \\
\text { UU Hak Cipta }\end{array}$ & $\begin{array}{l}14 \text { tahun dari tanggal } \\
\text { penerimaan }\end{array}$ & $\begin{array}{l}10 \text { tahun dari tanggal } \\
\text { permintaan, tetapidapat ber- } \\
\text { langsung terus bila diper- } \\
\text { panjang dan digunakan. }\end{array}$ \\
\hline BentukPelanggaran & $\begin{array}{l}\text { Secara substantif bagian- } \\
\text { bagiannya telah dikopi tanpa } \\
\text { izin, atau terdapatkesamaan }\end{array}$ & $\begin{array}{l}\text { Membuat, menjual, menye- } \\
\text { wakan, atau memakai pro- } \\
\text { ses atas hasil produksi } \\
\text { yang diberipaten tanpahak. }\end{array}$ & - \\
\hline Sanksi Pidana & $\begin{array}{l}\text { Maksimal7tahun daniatau } \\
\text { denda seratus juta rupiah }\end{array}$ & $\begin{array}{l}\text { Maksimal 7 tahun dan } \\
\text { denda seratus juta rupiah }\end{array}$ & $\begin{array}{l}\text { Maksimal 7 tahun dan } \\
\text { denda maksimal seratus } \\
\text { juta rupiah }\end{array}$ \\
\hline
\end{tabular}

\section{- Daftar Pustaka}

Koda, Henry dan Hiroto Yamamoto. 1995. Kompas. Tak Acuhkan Paten, Peneliti Bisa Senritsu no Patento Mafia. Jadi Pihak Merugi. 19 Agustus 1998.

Maulana, Insan Budi. "Patent Mafia atau Mafia Paten?". Kompas. 28 April 1997.

World Patent \& Trademark News. Vol. 1 No. 1. March 1998.

Warshoefsky, Fred. 1994. The Patent Wars, Undang-undang Paten No. 6 Tahun 1989.

the Battle to Own the World's Technology. John Wiley \& Sons. Inc.

Bisnis Indonesia. BPPT Usul PNBP Hasil

Karya Intelektual Gunakan Pos Audit. 20

Agustus 1998. 